\title{
THE HUBER ENIGMA: REVOLUTIONARY OR POLICE-SPY?
}

Any historian who deals with a period in which conspirators played a significant role sooner or later comes up against the conspirator's twin brother, the undercover police agent. In most cases, the policeman revolutionary or revolutionary policeman, however fascinating as an entrée into the twilight world of double and triple agents, offers more to the enterprising journalist than to the historian. Even some of the more spectacular exemplars of real or reputed undercover agents Roman Malinovsky, who rose to membership in the central committee of the Bolshevik party before 1917; Lucien Delahodde, who until his exposure was a leading light in the secret societies of the July Monarchy;2 Auguste Blanqui, the unquenchable revolutionary who may or may not have informed on his comrades in $1839^{3}$ - did not really affect the general course of history, at least not as informers. Though Malinovsky as a psychological phenomenon cries out for a latter-day Dostoevsky, his amazing career did not in any way deflect the Bolsheviks from their goal. Delahodde's more businesslike relations with the Orleanist police sapped an underground republican movement which was already impotent and discredited before he joined it. In Blanqui's case, the question of guilt or innocence is almost irrelevant, though the accusation of treason which the journalist Taschereau levelled in March 1848 did foil Blanqui's efforts to lead the left-wing opposition to the Provisional Government.

\footnotetext{
1 See Bertram D. Wolfe, Three Who Made a Revolution (Boston: Beacon Press, 1960), pp. 535-557.

2 Mémoires de Caussidière (Paris: Lévy, 1849), I, pp. 145-156; A Chenu, Les Conspirateurs (Paris: Garnier, 1850), pp. 145-152.

3 There is a considerable literature on the question of Blanqui's "guilt". Among the major contributions are Suzanne Wassermann, Les Clubs de Barbès et de Blanqui (Paris: Cornély, 1913), pp. 105-136; J. F. Jeanjean, Armand Barbès (1809-1870) (Paris: Cornély, 1909), I, pp. 170ff.; C. Geffroy, L'Enfermé (Paris: Charpentier, 1897), pp. 147ff.; and, more recently, Maurice Dommanget, Un Drame politique en 1848 (Paris: Les Deux Sirènes, 1948), and several articles by the same author.
} 
At least one such drama of questionable loyalities during the period of the Second Republic goes beyond la petite histoire by significantly affecting our interpretation of the French Revolution of 1848: the enigma of Aloysius Huber, club leader and revolutionary veteran, also clouds the revolutionary journée of May 15, 1848. That day Huber led a mass march of clubists and other sympathizers to the National Assembly to present a petition in behalf of aid for the beleaguered Poles. The demonstration got out of hand, a mob invaded the assembly hall, and in the end Huber proclaimed the dissolution of the recently elected parliament. Huber's intervention transformed an unarmed, if disorderly, demonstration into an insurrection crushed within the hour. May 15 was to provide an unsympathetic government and parliament with an opportunity for discrediting the Socialist clubs, imprisoning their first-string leaders, and setting the scene for the final days of reckoning in June. In his hour of dubious glory on May 15, had Huber merely played the role of a sincere, if inept, Socialist-Jacobin agitator, or had he deliberately set off the spring of a cunningly baited trap?

In short, was the journée of May 15 neither a left-wing conspiracy nor an accident but a well-oiled police operation? ${ }^{1}$ The aim of this paper is not to reconstruct the intricate chain of events leading to the dissolution of the National Assembly, ${ }^{2}$ but to examine the credibility of the charges of double-dealing levelled against Huber in 1849, for upon these hinges the interpretation of May 15 as a police provocation.

The personality and career of Aloysius Huber are vintage romantic melodrama that restores one's faith in the verisimilitude of the most outrageous pages of Victor Hugo's Les Misérables or even of Eugène Sue's Les Mystéres de Paris. Born in Alsace in 1813, Huber, who had been educated "above his station", ${ }^{3}$ was sent by his parents to Paris to live with an uncle who ran a wineshop. ${ }^{4}$ After two years the boy broke with his relative and was eventually apprenticed to a currier. Already young Huber evoked what was to be the stock description of him by those who knew him: a good heart and a hot temper. The very master currier who had fired him for talking back was to testify to his character

1 Supposedly masterminded by Armand Marrast, the anti-Socialist mayor of Paris. This interpretation was not uncommon in contemporary accounts of the Revolution of 1848 . More recently, it was very persuasively expounded in Henri Guillemin, La Tragédie de 1848 (Geneva: Milieu du Monde, 1948), pp. 231-257. ${ }^{2}$ I have recently undertaken such a critical reconstruction as part of a forthcoming monograph on the Paris club movement in 1848.

3 Affaire du complot de Neuilly, Indictment, March 8, 1836, Le Moniteur universel, 1836, p. 570.

4 Affaire Hubert [sic!], Session of May 7, 1838, Interrogation of Huber, Le Moniteur universel, 1838, p. 1184. 
during Huber's first trial. ${ }^{1}$ His lifelong friend and fellow currier, Moulin, agreed that Huber was an incorrigible hothead, yet also pictured him as a man who pawned his only overcoat to help an unemployed neighbor with six children. ${ }^{2}$

Huber, who had been active in the semilegal Société des Droits de l'Homme of the early thirties, made his first public appearance in May 1836 as one of thirteen defendants in what became known as Neuilly Conspiracy. Huber distinguished himself among the defendants by drawing a one-year sentence even before the main trial opened. $\mathrm{He}$ had been charged with "insulting the arresting police inspector while in the exercise of his duties", "uttering seditious cries", "insulting and abusing the investigating magistrate" over and above the principal indictment of plotting against king and country. ${ }^{3}$ The conspiracy, which centered on a plan to assassinate Louis-Philippe en route to his palace in Neuilly, was a very amateurish affair that had never really reached threatening proportions. It is even conceivable that this handful of self-important young republicans, most of them in their early twenties, was led on by a ubiquitous police informer who was to be star witness for the prosecution. Huber was among the five defendants who were found guilty. Characteristically, the courtroom proceedings ended in such an uproar - Huber delayed the pronouncement of the actual sentence of five years by flying into a wild tirade that the young Alsatian conspirator, ejected on the judge's orders, was absent when his sentence was read. ${ }^{4}$ By sheer luck, Huber's first stint as a political prisoner was brief. A general amnesty, proclaimed on the occasion of the crown prince's marriage in May 1837, freed all political prisoners. $^{5}$

Eight months later Huber was back behind bars and in far more serious trouble. One December night a billfold had fallen out of Huber's pocket in the midst of a driving rain as he ran past a customs guard at

1 Affaire du complot de Neuilly, Session of April 4, 1838, Testimony Cleris, Le Moniteur universel, 1838, p. 629.

2 Affaire du complot de Neuilly, Session of April 4, Testimony Moulin, Le Moniteur universel, 1838 , p. 629.

3 Affaire du complot de Neuilly, Indictment, March 8, 1836, Session of March 28, Interrogation of Huber; Session of March 30, Testimony policeman Cayet; Session of April 8, sentences. Le Moniteur universel, 1836, pp. 570, 581-582, 590, 677-678. For a brief (and hostile) account of the affaire from the point of view of the police, see Mémoires de M. Gisquet, ancien préfet de police (Paris : Marchant, 1840), IV, pp. 122-139.

4 Affaire du complot de Neuilly, Session of April 8, 1836, Le Moniteur universel, 1836, p. 678.

${ }^{5}$ Louis Blanc, Histoire de Dix Ans (Paris: Pagnerre, 1844), V, p. 240, Paul Thureau-Dangin, Histoire de la Monarchie de Juillet (Paris: Plon-Nourrit, 1905), 4th ed., III, pp. 195-197. 
Boulogne. ${ }^{1}$ The billfold was found to contain letters incriminating Huber and several other republicans in a plot to murder the king by means of an "infernal machine" or, more accurately, some sort of primitive machine gun. ${ }^{2}$ This Affaire Huber must surely rate as one of the most harebrained conspiracies on record. It involved the financing by French republicans of an untested multiple gun to be constructed in England by the son of its Swiss inventor named Steuble. This gun, which apparently never left the drawing board (and there may not even have been a drawing board), was to be used - and here the tale varied - to kill the king and his entourage, to mow down all of the deputies while they stood on the steps of parliament, or to spark a general revolution. The credibility of this bizarre tale was not enhanced by the prosecution's key witnesses, two informers with police records as forgers. ${ }^{3}$ Aside from Huber and young Steuble, the chief defendant was an extraordinary young woman, Laure Grouvelle. Mlle Grouvelle, overcoming the handicap of a respectable bourgeois background (though her father had been Louis XVI's jailer at the Temple), was a republican Joan of Arc in search of a stake. She had fearlessly nursed victims of the cholera epidemic of 1832; she devoted time and ingenuity to succouring the families of political prisoners; she also had an unnerving penchant for regicides, whose graves she tended with loving care and whose relics she treasured. ${ }^{4}$ She seems to have been attracted to Huber because in her eyes he had the heroic dimensions (physique included) of a potential king-killer. ${ }^{5}$

All three of the major defendants were convicted. Huber, whose sentence was read first, stoically accepted life imprisonment. Steuble was given five years. When Laure Grouvelle also drew a sentence of five years, Huber suddenly flashed a hidden knife and tried to stab himself before the startled courtroom. The trial ended in a wild mêlée as policemen wrestled down the herculean Huber (who shouted, "You

\footnotetext{
1 Affaire Hubert, Session of May 16, 1838, Testimony douanier Pauchet, Le Moniteur universel, 1838 , p. 1284.

2 For a brief and one-sided (sympathetic) account of the Affaire Hubert [sic!], see Louis Blanc, Histoire de Dix Ans, V, pp. 343-348. For the full savor of the trial and the personalities of the defendants, the day by day account in Le Moniteur universel is indispensable. Le Moniteur universel, 1838, pp. 1042-1046, 1179, 1184-1186, 1195-1197, 1225, 1237-1239, 1259-1260, 1270-1272, 1283-1284, 1294, 1311-1312, 1331-1332, 1379-1380, 1391-1392, 1395-1397.

3 Affaire Hubert, for information on Valentin, Session of May 15, 1838, Le Moniteur universel, 1838, p. 1271; for Schiller, see his testimony, Sessions of May 18 and 23, Le Moniteur universel, 1838, pp. 1311, 1391.

- Affaire Hubert, Session of May 8, 1838, Interrogation of Mlle Grouvelle, Le Moniteur universel, 1838, pp. 1184-1185. Mémoires de M. Gisquet, IV, pp. 88-89.

5 Le Moniteur universel, 1838, p. 1185.
} 
have condemned innocence herself!"), while Steuble quietly passed out in the dock. ${ }^{1}$ The aftermath had the same flavor of fourth-rate melodrama. Mlle Grouvelle went mad and died before her term expired. Steuble slit his throat in his cell. ${ }^{2}$ Huber as a long-term political prisoner who must already have had a name as a troublemaker was treated with unusual severity. ${ }^{3}$ Whatever the reasons, he was in and out of solitary confinement - twenty-two months at one stretch at the Mont Saint-Michel - in and out of leg irons, intermittently deprived of correspondence privileges. Huber's hunger strike at one such occasion threatened the government with an unwelcome cause célèbre. ${ }^{4}$ By 1843 he had contracted tuberculosis in the dank cells and was written off as a dying man. ${ }^{5}$ What saved Huber was not only his astonishing vitality, but also the loyalty and persistence of friends who agitated, lobbied, and cajoled the authorities into hospitalizing the prisoner. By this time he was spitting blood and no longer able to walk. After confinement in hospitals in both Paris and Tours, Huber recovered and was sent back to prison. Shortly before the February Revolution he had suffered a relapse and was again readmitted to Tours. ${ }^{6}$

On February 25, 1848, Huber, together with other political prisoners, was freed by order of the new Provisional Government. ${ }^{7} \mathrm{He}$ was so weak that he had to be carried on a mattress to the post coach which took him to Paris. ${ }^{8}$ When he arrived in the capital, all he possessed were the clothes on his back, the hundred francs allotted to liberated republicans, and his reputation as a revolutionary martyr ranking with Armand Barbès and Auguste Blanqui. Despite his poor health, Huber

${ }^{1}$ Louis Blanc, op. cit., V, p. 34-37.

2 Loc. cit.

${ }^{3}$ This was at least the stated opinion of two men who had shared Huber's captivity. Haute-Cour de Versailles, Session of October 11, 1849, Testimony Guignot, Nouguès, Le Moniteur universel, 1849, pp. 3063, 3064.

4 While Huber's spiritual autobiography, not published until 1862 but probably written during or before 1848 , deals chiefly with a conversion experience which took place in 1841, it does contain some interesting psychological insights into his captivity as well as scattered biographical information. See A. Huber, Nuit de veille d'un prisonnier d'état (Paris: Dentu, 1862), pp. 28-29, 32-33, 5658, 64-68, 93-115, 117-118, 150-153, 175-185, 218-220, 261-265, 280-281, 298-304, 310-313.

${ }^{5}$ For Huber being written off as moribund, see Louis Blanc, op. cit. ,V, p. 348. For Huber's long imprisonment, Haute-Cour de Versailles, Session of October 11 , 1848, Testimony Moulin, Guignot, Mme Moulin, Le Moniteur universel, 1849, pp. 3060, 3063-3064.

' Haute-Cour de Versailles, Session of October 11, 1849, Testimony Moulin, Guignot, Mme Moulin, Le Moniteur universel, 1849, pp. 3060-3061, 3063-3064. 'Archives nationales, F9, Dossier 770, Dispatch No 132 (February 25, 1848). 8 Haute-Cour de Versailles, Session of October 11, 1849, Testimony Moulin, Le Moniteur universel, 1849, p. 3060. 
immediately launched himself into the burgeoning club movement as one of the executive members of the revived Societe des Droits de l'Homme. ${ }^{1}$ Soon afterwards, he founded and presided over the Club démocratique du Progrès, while sponsoring an association of his compatriots, the Club démocratique des Ouvriers alsaciens. ${ }^{2}$ When late in March of 1848 the Club of Clubs was organized, Huber was elected president. ${ }^{3}$ A few days before the general elections of April, he left Paris for the département of Indre-et-Loire (where he had been hospitalized) in an unsuccessful bid for a seat in the Constituent Assembly. ${ }^{4}$ His second candidacy in Paris, though garnering more than forty thousand votes, was also unsuccessful. Upon his return to the capital after the April elections, he reorganized the Club of Clubs into a new coordinating body called the Comité centralisateur, which reluctantly sponsored the fatal demonstration of May $15 .^{\mathbf{5}}$

In the light of later charges that Huber had been bought by the authorities in 1848, how did Huber manage to live as a professional revolutionary in the months following his release when he could draw on neither personal nor family fortune? The evidence suggests that Huber had no great problems making ends meet. From February 23 to May 15, 1848 (after which he went into hiding and was supported by friends), he probably received about four hundred francs. This sum included the hundred francs handed to him upon his release, about two hundred for his services, first as full-time executive, then as republican "missionary" for the government-subsidized Club of Clubs, and a hundred francs awarded to a former fellow-inmate who turned it over to Huber. ${ }^{7}$ To put this income in perspective, during the same twelve weeks an unemployed worker at the National Workshops

1 Poster (March 3 [?], 1848), Les Murailles révolutionnaires, ed. A. Delvau (Paris: Bry, 1852), I, p. 261.

2 For Huber's presidency of the Alsatian Club, see Archives nationales, C. 942, Commission d'enquête No 8396. For his presidency of the Club du Progrès, La Commune de Paris, March 26, 1848.

${ }^{3}$ Longepied and Laugier, Comité révolutionnaire, Club des Clubs et la Commission (Paris: Garnier, 1850), p. 78. Haute-Cour de Versailles, Session of October 10, 1849, Interrogation of Huber, Le Moniteur universel, 1849, p. 3044.

4 Haute-Cour de Versailles, Session of October 10, 1849, Interrogation of Huber, Le Moniteur universel, p. 3044.

${ }^{5}$ Haute-Cour de Versailles, Session of October 13, 1849, Huber's plea, Le Moniteur universel, 1849 , p. 3080.

"Members of the board drew a per diem of 5 francs, "missionaries" 8 to 10 francs while travelling. Interrogation Delaire, Rapport de la commission d'enquête sur l'insurrection qui a éclaté dans la journée du 23 juin et sur les événements du 15 mai (Paris, 1848), I, p. 210. Longepied and Laugier, op cit., p. 57.

7 Haute-Cour de Versailles, Session of October 11, 1849, Testimony Chilmann, Le Moniteur universel, 1849, p. 3064. 
might have drawn no more than a hundred francs (plus food allowances and free medical care) ; ${ }^{1}$ a fully employed semiskilled worker (of whom there were few during the economic crisis of 1848), about two hundred and twenty $;^{2}$ a white collar employee, about three hundred and thirty. ${ }^{3}$ That may be why Huber, who was doing well compared to many other former prisoners, never bothered to apply to the Commission des Récompenses nationales for the compensation and job preferment to which he was entitled.

At the same time the initiative and persistence of his friends made up for Huber's abnegation. They lobbied endlessly to find him a government job, and two days before the demonstration of May 15 did succeed in getting a minor sinecure for him - Victor Hugo characterized the governorship of the Château de Raincy as "un pré et deux vaches" - with a salary of between two and three thousand francs per annum. Ironically, the day before, speaking before a meeting of disgruntled former political prisoners, Huber had publicly and magnanimously committed himself to declining any position until all his old comrades were decently placed. ${ }^{4} \mathrm{He}$ was still pondering this selfimposed dilemma when the events of May 15 foreclosed on his decision.

Before finding shelter with friends and going into hiding for ten months, Huber had had a narrow escape to which his detractors were to pont as evidence of official collusion: about $6 \mathrm{p}$. m. on May 15, he was arrested by national guards who had heard rumors that he had dissolved the National Assembly. Brought before the mayor of the fourth arrondissement, he was released for lack of evidence. ${ }^{5}$ From his

1 Donald C. McKay, The National Workshops (Cambridge: Harvard University Press, 1933), p. 26, fn. 25.

${ }^{2}$ Assuming per diem wages of 3 trancs; the range among Paris workers varied considerably. See Georges Duveau, De 1848 à nos jours, Vol. IV of Histoire du Peuple français (Paris: Nouvelle Librairie de France, n.d.), pp. 90-103.

${ }^{3}$ A yearly salary of about 1500 francs seems to have been standard for clerical work in both government and private employment. The Club of Clubs, for instance, paid its (male) secretaries 125 francs per month.

4 Haute-Cour de Versailles, Session of October 11, 1849, Testimony Moulin, Chilmann, Le Moniteur universel, 1849, pp. 3060-3061, 3064. For Huber's own attitude, Session of October 13, 1849, p. 3079.

${ }^{5}$ While the leader of the arresting national guards, a Dr Sée, and Lemor, the mayor, were to disagree vehemently as to whether the dissolution of the Assembly was mentioned at all, there is no doubt that Sée and his fellow guards acted on no more than hear-say and apologized to Huber upon his release. Huber himself was evidently a cool bluffer. Quite aside from the administrative investigating commission, called upon the subsequent request of Lemor himself to look into this incident (and which cleared Lemor of any wrong-doing), it is highly unlikely that Lemor acted upon higher orders - from Armand Marrast, mayor of Paris. As there was no possibility of predicting either Huber's arrest 
hiding place, Huber not only claimed full credit and blame for the dissolution of May 15, but in a private letter to Marie, a member of the Executive Commission who had shown interest in the political prisoner, he denied any link between the Polish demonstration and the June uprising in which, he claimed, he was not involved. ${ }^{1}$

Early in 1849 rumors reached Huber that Monnier, a former official of the Paris police prefecture, had discovered some letters dating from 1838, supposedly written by Huber to the police. Monnier, it was said, would testify on the sordid details before the High Court trying the leaders of the May 15 putsch. Huber thereupon scraped up enough money to go to England to demand an explanation from Marc Caussidière, the exiled ex-police prefect who had been Monnier's superior and was his childhood friend. While Huber was in England, Monnier did testify before the High Court at Bourges. Intent on clearing his name before fellow republicans, Huber felt honor bound to return to France and constitute himself prisoner, though he arrived too late to be tried with the other leaders of the May 15 demonstration. Huber was aware that in returning he faced a probable sentence of life imprisonment, ${ }^{2}$ which was indeed imposed by the High Court at Versailles in October 1849.

Though the documented charges against Huber's republican loyalty went back to 1837 and ' 38 and had no direct connection to the May 15, 1848, affair, the assumption prevailed that the police agent of the earlier date had reenacted his despicable role in 1848. At both the Bourges and the Versailles trials, Monnier, testified that several weeks after the events of May 15, he happened to stumble upon the Huber dossier in the archives of the police prefecture. The documents were sufficiently startling so that Monnier ordered his archivist to copy (and, in the case of a lengthy report, to summarize) them. Even though

or his arrest in one particular district (the national guards debated as to which mairie to take him), Marrast would have had to take twelve district mayors into his confidence. This would have been particularly risky since the district mayors were unpaid volunteers, many of them unsympathetic to Marrast's brand of conservative republicanism. Lemor himself, for one, was a member of the Société démocratique centrale headed by Guinard and Schoelcher which was considerably to the left of the republicans of Le National. For this incident, see Haute-Cour de Versailles, session of Oct. 11, 1849, testimony Huber, Sée, Lemor, Le Moniteur universel, 1849, pp. 3047, 3060, 3064. For his going into hiding, testimony Mme Moulin, ibid., p. 3064.

1 For Huber's letter on his role on May 15, see Rapport de la Commission d'enquête sur l'insurrection qui a éclaté le 23 juin 1848 (Paris, 1848), II, pp. 110-11; for his letter to Marie, dated July 2, 1848, see Gustave Glotz, "Les papiers de Marie", in: La Revolution de 1848, I (1904-05), pp. 157-58.

${ }^{2}$ Haute-Cour de Versailles, Session of October 12, 1849, Testimony Huber, Le Moniteur universel, October 13, 1849, p. 3081. 
Monnier submitted the copies to his superiors, the incident redeced in importance when the June insurrection came to overshadow the minor fracas of May 15. Monnier, transferred to another post in southern France, thought no more of it, but his archivist, Peggar, leaked news about the incriminating documents to one of the accused club leaders, François Raspail. ${ }^{1}$ Raspail then requested Monnier's presence in the witness stand.

Only copies of the documents were ever produced in court, as the public prosecutor's lukewarm request for the originals was turned down by the police prefect. ${ }^{2}$ Since the great bulk of the police archives went up in flames in 1871, the twentieth-century historian is no better served than was the nineteenth-century jury. Yet both Monnier and his archivist steadfastly maintained that the originals of the documents that they had copied did come from Huber's file and appeared to be in his handwriting. ${ }^{3}$

Could Monnier and his archivist have fabricated the incriminating documents, as similar documents may well have been manufactured or doctored to torpedo Blanqui in March 1848? What could be gained by discrediting Huber as an old-time agent provocateur except to suggest that he had played the same role on May 15? Therefore, the defendants facing the High Court at Bourges were the victims of a police frame-up, rather than the perpetrators of a political crime to be found "not guilty" by the jury. Yet such an argument would have seemed less than seductive in the atmosphere of growing political reaction which marked the year 1849. Left-wing republicans were not unaware that this was a political trial at which the victors disposed of the vanquished. ${ }^{4}$ It was hardly an accident that a specially constituted tribunal of

1 Haute-Cour de Versailles, Session of October 11, 1849, affidavit of Peggar, Le Moniteur universel, 1849, p. 3063.

2 On the specious grounds that no such dossiers would ever be retained in the police archives, an assertion that was demonstrably false. Haute-Cour de Versailles, Session of October 11, 1849, letter of Rebillot, police prefect, to the general procurator, October 4, 1849, Le Moniteur universel, 1849, p. 3063.

${ }^{3}$ Haute-Cour de Versailles, Session of October 11, 1849, affidavit of Peggar; Session of October 12, Testimony Monnier, Le Moniteur universel, 1849, pp. $3063,3076$.

4 For example, in a letter from the Minister of the Interior to the Minister of

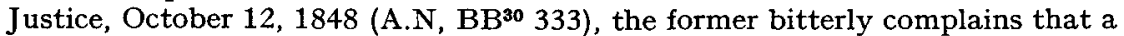
magistrate testified in behalf of Raspail, one of the accused of the May 15 affair. "Je ne considère pas," the minister went on, "que Raspail est en cause puisque Raspail à mes yeux n'est pas coupable; mais il s'agit de savoir si l'administration de la justice n'est pas une dérision. Comment!. . . le parquet est chargé d'instruire, et par esprit de corps, afin de faire voir qu'il est puissant et considéré, le parquet devrait chercher à enterrer ses ennemis, et c'est lui, lui parquet, qui 
questionable legality but of unimpeachable conservatism had been selected to try the case, far removed from the capital where public opinion sympathetic to the defendants might have influenced the decision. ${ }^{1}$ As assaults on the integrity of one of the defendants was highly unlikely to free the others, there really was not much point in spinning such an elaborate yet ineffective intrigue. In the absence of any evidence to the contrary save Huber's say-so, Monnier's testimony is best accepted at face value.

Let us assume, then, that the texts of the three documents read into the trial record by Monnier are authentic. The first, an undated note said:

Monsieur le préfet,

Avant mon départ de Paris, je vous prie de m'accorder une audience particuliere, mais surtout que ma communication avec vous ait lieu dans une autre prison que celle de mes co-accusés, afin qu'ils ignorent complètement nos relations. ${ }^{2}$

A second letter, written later, stated:

Monsieur le préfet,

Beaulieu, le 10 août 1838

Grâce à la réponse du ministre qui m'accorde l'autorisation d'écrire, j'ai terminé le travail que je vous avais promis. Il y a plus que les preuves de ce que je vous ai avancé et de ce que vous m'avez demandé à notre dernier entretien. Je n'ose les confier à la poste; veuillez donc m'enseigner un autre expédient plus sûr, afin que je puisse vous l'envoyer de suite. ${ }^{3}$

In the third document, a lengthy summary of Huber's report mentioned in the second letter, the alleged agent ostensibly explains that he became involved in the Steuble and Grouvelle plot only to be of service to the king who had pardoned him. Huber goes on to claim that on three separate occasions, using three different aliases and disguised handwritings (supposedly reproduced in the original report), he had denounced the plot and himself. Each time he had expected to

se démolit, qui atténue la culpabilité de ses adversaires." The "innocent" Raspail was to be sentenced to six years' imprisonment in 1849 .

1 Haute-Cour de Bourges, Session of March 7, 1849, statement by Raspail, Les Accusés de 15 mai devant la Haute-Cour de Bourges (Paris, 1849), pp. 36-39, which outlines the questionable procedure followed.

2 Haute-Cour de Versailles, Session of October 11, 1849, Testimony Monnier, Le Moniteur universel, 1849, p. 3061.

3 Loc. cit. 
be arrested immediately only to be left at large. Finally, puzzled by his continued freedom and anxious to nip the conspiracy, he had deliberately dropped his billfold within sight of the Boulogne customs official in order to force the hand of the authorities. The report concluded with these words, which Monnier's archivist had reproduced verbatim:

“Je n'ai fait que remplir un devoir, il est vrai; mais je l'ai fait par gratitude, tandis que d'autres l'auraient fait par calcul. Maintenant je pense que le roi n'oubliera non plus ce qu'il me doit à son tour."1

Assuming for a moment that these documents really prove Huber to have been an agent provocateur in 1837, what is the likelihood of his repeating such a performance under the moderate republican regime of 1848 ? Not very great! If Huber had indeed betrayed the conspiracy of 1837, his official reward had been ten years of the harshest imprisonment from which only the February Revolution had rescued him. It would take an exceptionally trusting nature to repeat the performance, unless we assume that Huber could be blackmailed into playing the assigned ignoble role. Yet if we are to believe Monnier and his associate - upon whose testimony the entire case rests - the incriminating documents were not discovered until several weeks after the May 15 affair. If, on the other hand, we assume that Huber was for sale, his role on May 15 was singularly unprofitable. The one substantial, tangible reward within his grasp, the governorship of Raincy, evaporated as a direct consequence of his involvement in the putsch. The fact that Huber's sentence of life imprisonment - the death penalty for political crimes having been abolished - was the harshest penalty that the court could impose does not suggest an atmosphere of official complicity either.

Yet to assume, as I have, the reliability of Monnier's testimony is not to imply that Huber's secret correspondence with the police prefect was what it seemed. If we were to accept Huber's revelations at face value, we would have to believe all of the following:

1) that in his interview with the police prefect, Huber had been unable to convince that official that he had indeed been an informer; 2) that Huber turned agent provocateur (since he was actually pushing the plot, his role went beyond that of simple informer) in gratitude for an amnesty applying to all political prisoners;

3) that he began to send anonymous letters incriminating himself by name (as well as his accomplices) without prior arrangement with

${ }^{1}$ Le Moniteur universel, 1849, p. 1032. 
the judicial or police authorities and without insuring special treatment for himself;

4) that besides the two professed police informers in the case, a third police informer, Huber, never publicly revealed himself. Of the first two, one was cited merely as a witness, while the second, though indicted, was freed for turning state's evidence; whereas Huber, the third informer, drew the heaviest sentence among all the defendants. 5) that Huber denounced Laure Grouvelle, yet attempted suicide, or staged an attempted suicide, upon hearing her sentenced;

6) that as a reward for denouncing a dangerous plot against the king's life, the police and judicial authorities not only sanctioned Huber's life term, but also treated him with unusual harshness in prison and never relented;

7) that a garden-variety stool pigeon would return to France to face certain life imprisonment in order "to clear his honor".

One, two, or even three of these conclusions can be accepted with a rueful shrug and a commonplace about the complexities of human nature. To accept all seven is to strain even the most wide-eyed credulity: if Huber did enter into communication with the police in 1838 - and I think he did - his "revelations" simply do not add up. Furthermore, the veracity of Huber's "revelations" can be checked in at least two ways, both of which point to a negative verdict. In the first place, Huber, in explaining his arrest to the police prefect, mentioned that he had deliberately dropped the compromising billfold in order to speed the arrest of the plotters, himself included. Yet one of the documents cited by the prosecution during the 1838 trial was a letter from Huber to Mlle Grouvelle, dated December 9, 1837, the day after his loss and before his arrest. In this letter Huber explained his predicament, warning her that the billfold might incriminate them all. ${ }^{1}$ A less formidable woman than Laure Grouvelle might well have been induced to cross the nearest frontier. In short, if Huber wanted to see his accomplices arrested, why did he warn them? In the second place, in his report to the police prefect, Huber claimed that just before leaving England for Boulogne a few days before his arrest on December 10, he had mailed a letter - supposedly his third - signed Valler, to Marshal Sebastiani, the French ambassador to the Court of Saint James, to denounce the plot against the king's life, naming himself and his accomplices. While other such purported letters to police prefect Delessert would presumably have gone up in smoke, the diplomatic dispatches from the French ambassador in London have been impeccably preserved in the Archives des Affaires étrangè-

1 Affaire Hubert, Session of May 14, 1838, Le Moniteur universel, 1838, p. 1259. 
res. Had Sebastiani really been warned of such a plot, it is inconceivable that the would not have passed on this information. Yet neither Valler nor Huber nor any threat of regicide are mentioned in Sebastiani's dispatches for the period. ${ }^{1}$

If Huber in 1838 went to great lengths in claiming a shady past to which he was not entitled, what was his motive? Even though Huber's public stance was to deny his authorship of any incriminating letters, he seems to have offered another explanation in private during his visit to London in February 1849. Both Caussidière and Louis Blanc later contended that Huber had attempted an explanation which they accepted as reasonable. Huber had told them that, driven to desperation and panic by solitary confinement, he had written letters to the authorities promising revelations - anything to gain a transfer from his prison and find some chance for escape. ${ }^{2}$ That Huber had not lived up to the superhuman code demanded of republican revolutionaries can also be substantiated by yet another incident. Not long after the February Revolution, Huber and several other ex-political prisoners raided the Bureau des grâces of the Ministry of Justice for their respective dossiers which were never returned. ${ }^{3}$ That Huber had such a file proves that he had applied for clemency, something which would not have sat well with the self-appointed guardians of revolutionary integrity.

Huber was by no means exceptional in buckling under the strain of isolation: one need only think of Bakunin's imprisonment and his groveling letter to the Tsar, ${ }^{4}$ a letter that hardly takes the measure of its author. Perhaps more immediately pertinent are the comments of Gisquet, police prefect of Paris until 1837, who in his memoirs mentioned the frequent letters from prisoners who asked to see him "pour faire d'utiles communications". Gisquet was to learn from experience that these were almost always a pretext, "une ruse imaginée dans la vue de changer instantanément de localité, et de se créer une chance

1 Archives des Affaires étrangères, Angleterre 650 (October 1837-1838). I had dispatches F046 (November 2) to F0142 (February 6, 1838) checked.

2 For Huber's own interpretation, see Haute-Cour de Versailles, Session of October 12, 1849. Letter from Huber to Louis Blanc, Le Moniteur universel, 1849, p. 3077 ; for Caussidière's, Haute-Cour de Versailles, Session of October 11, 1849, affidavit by Peggar [ex-archivist of the Paris police prefecture], Le Moniteur universel, 1849, p. 3063; for Louis Blanc, letter to Huber, ibid., p. 3077, and Louis Blanc, Histoire de la Révolution de 1848 (Paris: Marpon \& Flammarion, 1880), II, pp. 78-80.

3 A.N., BB21 549, Registre S, Dossier No 3322, Huber, "inculpation et demande en grâce".

4 E. H. Carr, Michael Bakunin (London: The Macmillan Company, 1937), Vintage Book reprint, pp. 221-228. 
d'évasion". ${ }^{1}$ Gisquet, consequently, rarely granted such interviews, though this was a lesson which his successor Delessert, in office less than a year at the time of his interview with Huber, was not yet likely to have learned.

Huber's later career did nothing to vindicate the purity of his republican convictions, though few of his critics could speak from his perspective of fourteen years spent behind bars. As ever, the Alsatian could not resist the flamboyant gesture: unlike other political prisoners who were pardoned after penning many a humble supplication to the Minister of Justice, Huber gained his freedom in 1852 by a direct appeal to the Prince President (though it may have been LouisNapoleon who arranged for the publication of the letter), ${ }^{2}$ hailing the regime's plebiscite as the voice of the people and promising therefore to abstain from further republican agitation. Huber's panache - and his renewed bout with tuberculosis - struck just the right note; he was not only freed but his request for a minor government appointment seems to have been honored. ${ }^{3}$ Such a break with the standards of republican decorum had already been foreshadowed at his 1849 trial, at the end of which he damned fellow Socialists like Blanqui, Raspail, and Caussidière for making him the sacrificial goat of the republican party.

In short, Huber ends up as something less than an enigma, as a revolutionary who bent rather than broke under pressure. Though he was not cast in the heroic (and slightly idiotic) mold of an Armand Barbès who in 1853 had to be expelled from prison because he would not accept an imperial pardon, neither was Huber a traitor to the revolutionary cause he served. As for his role on May 15, 1848, not a shred of evidence supports the charge that Huber's dissolution of the National Assembly was anything other than the characteristic gesture of a notoriously temperamental man. To make Huber the kingpin of an anti-Socialist police plot is to deal in mythology rather than in history.

1 Mémoires de M. Gisquet, IV, pp. 384-385.

2 The letter which appeared in Le Moniteur des Communes, February 23, 1852, is reprinted by J. Bossu, "Il y eut en 1848 Huber et Hubert", in: La Révolution de 1848 , XXXVI, p. 77.

3 For the report on Huber, dated February 10 [1852], from the Minister of Justice to the Prince-President, see A.N. BB ${ }^{21}$ 549, Registre S, Dossier No 3322 [Huber]. The anonymous author of the notice on Huber in P. Larousse, Grand Dictionnaire universel, Vol. H-K, p. 426, claims to have seen the letter of February 29, 1852, in which Huber requested a government position.

4 Haute-Cour de Versailles, Session of October 13, 1849, Le Moniteur universel, 1849, pp. 3078-3079. 